\title{
COMPARISON OF MONTELUKAST VERSUS SALMETEROL AS ADD-ON TO INHALED FLUTICASONE IN AT-RISK ASTHMATIC CHILDREN POSSESSING THE HOMOZYGOUS ARGININE-16 B B $_{2}$ ADRENOCEPTOR GENOTYPE- A RANDOMIZED CONTROLLED TRIAL
}

K. Basu ${ }^{1,2}$, H.P. Donald ${ }^{2}$, B.J. Lipworth ${ }^{3}$, R. Tavendale ${ }^{4}$, D.F. Macgregor ${ }^{2}$, S.A. Ogston ${ }^{5}$, C.N. Palmer ${ }^{4}$, S. Mukhopadhyay ${ }^{1,2}$

${ }^{1}$ Academic Department of Paediatrics, Brighton and Sussex Medical School, University of Sussex, Brighton, ${ }^{2}$ Children's Asthma and Allergy Unit, Perth Royal Infirmary, NHS Tayside, ${ }^{3}$ Asthma and Allergy Research Group, Division of Medicine and Therapeutics, ${ }^{4}$ Population Pharmacogenetics Group, Biomedical Research Institute, ${ }^{5}$ Division of Clinical and Population Sciences and Education, University of Dundee, Dundee, UK

Background and aims: Although clinical response is often variable, salmeterol is at least as effective as montelukast as add-on controller in children with asthma. However, children taking salmeterol, homozygous for the arginine-16 (Arg16) allele of ADRB2, have more frequent asthma exacerbations.We therefore investigated long term asthma control in genetically susceptible children with Arg/Arg-16 who were randomized to receive montelukast or salmeterol as add-on to inhaled steroid.

Methods: 62 asthmatic children with the Arg/Arg16 genotype were randomly assigned to receive fluticasone (as Flixotide ${ }^{\circledR}$ ) plus either oral montelukast, or salmeterol (as Seretide ${ }^{\circledR}$ ) with placebo montelukast. The primary end-point was school absence over one year. The study was funded by an unrestricted educational grant from MSD, UK.

Results: Reliever use was significantly decreased with montelukast compared with salmeterol $(0.47(95 \% \mathrm{CI}$, $0.16-0.79 ; \mathrm{p}=0.004)$ ). Symptom scores improved with montelukast compared with salmeterol (morning cough: $0.51(95 \% \mathrm{CI}, 0.09-0.92 ; \mathrm{p}=0.018)$; morning wheeze: $0.55(95 \% \quad \mathrm{CI}, 0.25-0.86 ; \mathrm{p}=0.001)$; morning dyspnoea: $0.29(95 \% \mathrm{CI}, 0.06-0.53 ; \mathrm{p}=0.008)$; night wheeze: $0.46(95 \% \mathrm{CI}, 0.15-0.77 ; \mathrm{p}=0.004)$; night dyspnoea: $0.44(95 \% \mathrm{CI}, 0.16-0.73 ; \mathrm{p}=0.001)$. A significant improvement in pediatric asthma-related quality of life scores was observed with montelukast compared to salmeterol (activity limitation score: $-0.55(95 \% \mathrm{CI},-0.918$ - $0.18 ; \mathrm{p}=0.004)$, symptom score: $-0.53(95 \% \mathrm{CI},-0.92--0.14 ; \mathrm{p}=0.009)$, emotional function score $-0.523(95 \%$ CI,-0.84- $-0.20 ; \mathrm{p}=0.002)$ ). No significant difference was observed in school absences $(0.40(95 \% \mathrm{CI},-0.07-$ $0.87 ; \mathrm{p}=0.097)$ ) between the treatment groups.

Conclusions: In children with Arg/Arg-16 genotype, montelukast may be more effective than salmeterol as add-on controller. This contrasts with the overall population of asthmatic children where salmeterol is more effective than montelukast. There is need to explore the feasibility and cost-effectiveness of ADRB2 genotype-directed choice of controller therapies in asthmatic children. 